\title{
Tillage systems and cover plants change organic fractions of phosphorus in oxisol of eastern Amazonia
}

\author{
Rafael Silva Guedes ${ }^{1, *}(\mathbb{D})$, Luís Reynaldo Ferracciú Alleoni² (iD, Benedito Luiz Correia³ (D), Luis Wagner \\ Rodrigues Alves $^{4}$ (D), Sílvio Junio Ramos ${ }^{1}$ (D), Antonio Rodrigues Fernandes ${ }^{5}$ (D) \\ 1. Instituto Tecnológico Vale Desenvolvimento Sustentável - Tecnologia Ambiental - Belém (PA), Brazil. \\ 2. Universidade de São Paulo - Escola Superior de Agricultura “Luiz de Queiroz" - Departamento de Ciência do Solo - \\ Piracicaba (SP), Brazil. \\ 3. Universidade Federal Rural de Pernambuco - Colégio Agrícola Dom Agostinho Ikas - São Lourenço da Mata (PE), Brazil. \\ 4. Empresa Brasileira de Pesquisa Agropecuária - Centro de Pesquisa Agroflorestal do Amapá - Macapá (AP), Brazil. \\ 5. Universidade Federal Rural da Amazônia - Instituto de Ciências Agrárias - Belém (PA), Brazil.
}

\begin{abstract}
Due to the large extent of degraded areas in the Amazon, the use of conservation systems is very important to contain the advance of the agricultural frontier, and may favor the availability of nutrients such as phosphorus $(P)$. This study evaluated effect of tillage systems on and cover plants distribution of organic $P$ fractions (Po) in oxisol under soybean and grasses in crop successions. The experimental design was completely randomized with four replicates and five treatments: (i) conventional tillage (CT) with annual soil tillage; (ii) no-till (NT) in succession with Urochloa ruziziensis (NT1); (iii) NT in succession with U. brizantha (NT2); (iv) NT in succession with Panicum maximum (NT3); and (v) a control consisting of a fragment of native vegetation (NV). The Po fractions were quantified at depths of 0-5, 5-10, and $10-20 \mathrm{~cm}$, before and after soybean cultivation and the $P$ fractions were analyzed. The samples at a depth 0-5 and 5-10 cm had increased levels of biomass P in the NT1 and NT2. In addition, at depths of $0-5$ and $5-10 \mathrm{~cm}$, the treatments in no-tillage systems accumulated the most of the Po labile fractions. These results showed that conservation systems tend to accumulate most of the $P$ fractions in soil through decomposition of organic residues. Thus, no-tillage system was shown to be important for Po supply, where the use of $U$. brizantha 'Piatã' (NT2) favored higher levels of organic $P$ in labile and moderately labile fractions in soil, which was considered the best alternative for Po supply among the species tested.
\end{abstract}

Key words: Glycine max, organic phosphorus fractionation, humic fractions, no-till.
Received:

Sep. 23, 2019

Accepted:

May 24,2020

Section Editor:

Osvaldo Guedes Filho

${ }^{\star}$ Corresponding author: rafael.guedes@pq.itv.org

\section{INTRODUCTION}

Oxisols cover $32 \%$ of the Brazilian territory and occur throughout the country under a variety of different edaphic and climatic conditions (Santos et al. 2011). They are the most widespread soil type in the Brazilian Amazon and extremely important for that region, where they are the most common soil type in agricultural lands. These soils are poor in nutrients mainly in available phosphorus (P) (Quesada et al. 2011).

Phosphorus added either as mineral or organic fertilizer tends to migrate out of the soil solution and into the solid phase, making these soils a P sink; however, they can be transformed from less to more labile forms and become a source of $\mathrm{P}$ in weathered tropical soils depending on the soil management system (Zamuner et al. 2008).

The tillage systems and the quantities of $\mathrm{P}$ applied and exported from soils determine which $\mathrm{P}$ forms accumulate within soils (Tiecher et al. 2012). Phosphorus accumulates in the surface layer $(0$ to $10 \mathrm{~cm}$ ) when soils are cultivated over long 
time periods using soil-conservation management strategies and tends to accumulate as organic fractions (Redel et al. 2007). However, soils that are subject to conventional agriculture tend to accumulate inorganic poorly labile forms of $P$ (Zamuner et al. 2008), due to ploughing and harrowing that facilitate oxidation and gradual reduction of organic matter (OM) contents. Rodrigues et al. (2016) confirmed that 70-85\% of $\mathrm{P}$ added was bound in inorganic forms associated to $\mathrm{Fe} / \mathrm{Al}$ oxyhydroxides. However, Rheinheimer et al. (2019) reported a significant increase in organic P fractions under no-tillage. This process depends on some factors such as $\mathrm{pH}$, microbial activity (Jin et al. 2006; Wang et al. 2017) and the management of soil organic matter, and should be considered in adapted rotation systems to obtain better crop yields (Leithold et al. 2015).

The cover crops may change the $\mathrm{P}$ dynamics in soils due to the recycling of $\mathrm{P}$ mobilized as plant residue promoting microbial activity. Thus, Tiecher et al. (2012) analyzed the effect of some species (as oat, radish, wheat and fallow) under conventional tillage (CT) and no-tillage (NT), observing the accumulation of organic residues increasing the Po content in the soil.

Forage species are highly recommended as cover plants due to their ability to accumulate $\mathrm{P}$ and incorporate them into the soil; however, it is desirable that these species have a high capacity for root and biomass production (Damon et al. 2014). Among forages widely used in agricultural production systems, Urochloa ruziziensis has been recommended as the main forage, because it has a deep rooting system and is highly productive, reaching a dry mass of $15 \mathrm{t} \cdot \mathrm{ha}^{-1} \cdot \mathrm{year}^{-1}$. The soil cover of Panicum maximum 'Massai' was analyzed by Valentim and Moreira (1994), who found $81-100 \%$ of cover and high adaptation in soils with low $\mathrm{P}$ and low moisture contents, while Urochloa brizantha c 'Piatã' has shown great potential in integrated production systems in addition to high growth $(60 \mathrm{~cm})$ as function as P fertilizing (Dan et al. 2011; Dias et al. 2015).

In some regions of Brazil (mainly south and southeast), conservation tillage and cover crops using forage species is well established using mainly Urochloa species (Ferreira et al. 2010). The soil cover promoted by forage species contributes to reducing erosion and leaching processes and improve the soil quality and productivity of crops (Sá et al. 2014). However, these systems have been recently introduced in the Brazilian Amazon, and their benefits are not well reported.

Fractionation or sequential extraction makes it possible to study $\mathrm{P}$ dynamics in soils by separating fractions with different extractants (Zhang and Kovar 2009). Understanding organic P fractions in no-tillage systems in the Amazon region based on plant cover crops in the early years of cultivation can be a tool that enables better use of $\mathrm{P}$ fertilization.

As highly weathered oxisols require high fertilizer application rates, the accumulation of $\mathrm{P}$ in the labile and moderately labile fractions, which are more accessible to the plants, may prevent excessive $\mathrm{P}$ in soils and reduces economic losses and environmental damage. Therefore, a detailed understanding of organic phosphorus (Po) fractions can help develop management strategies to maintain or increase crop productivity and to reduce the need for fertilization (Vincent et al. 2010). The authors of this work hypothesized that conservations systems and the cultivation of the cover crops may be a way to increase Po fractions in the soil. Therefore, this study aims to assess the effect of tillage systems on distribution of Po fractions in oxisol under soybean and grasses in crop successions.

\section{MATERIAL AND METHODS}

\section{Location and characterization of the experimental area}

The study was performed in Paragominas, located in the northeastern portion of Pará state, Brazil ( $02^{\circ} 51^{\prime} 54^{\prime \prime}$ 'S $48^{\circ} 23^{\prime} 40^{\prime \prime} \mathrm{W}$; elevation $88 \mathrm{~m}$ ). Soils in the region have been classified as oxisols (Soil Survey Staff 2014). The topography varies from flat to softly rolling slopes. The climate is classified as Aw, according to the Köppen classification, that is, a rainy tropical with a welldefined dry season, with an average annual temperature of $26.5^{\circ} \mathrm{C}$ and an annual rainfall of $1800 \mathrm{~mm}$ (Rodrigues et al. 2003).

In 2008, before the experiment was established, the entire area was prepared using conventional methods (light plowing and leveling). The no-tillage treatments (NT) were not lightly plowed or leveled between 2009 and 2011. The soybean seeding consisted of 12 plants $\mathrm{m}^{-1}$ with $45 \mathrm{~cm}$ row spacing. All treatments were fertilized receiving $350 \mathrm{~kg} \cdot \mathrm{ha}^{-1} \mathrm{of} \mathrm{NPK}$ (4-20-20 formula) annually applied superficially in the row planting. The experimental design was completely randomized with four tillage systems, one native area and four replicates: (i) a conventional tillage with one light plowing and two leveling annually in November (CT) of soybean (Glycine max) 'Sambaíba' cultivated three years in succession with rice (Oryza sativa) 
and maize (Zea mays) 'BRS 1030'; (ii) NT of soybean, cultivated three years in succession with Urochloa ruziziensis (NT1); (iii) NT of soybean, cultivated three years in succession with Urochloa brizantha 'Piatã' (NT2); (iv) NT of soybean, cultivated three years in succession with Panicum maximum 'Massai' (NT3) (Table 1); and (v) a fragment of native vegetation (NV). Soybean was always cultivated between February and May and the cover crops was grazed on August. The NV area was a 20 -year-old succession characterized by a complex association of woody-shrubby species.

Table 1. Evolution of treatments for evaluation.

\begin{tabular}{ccccc}
\hline Treatment & $\mathbf{2 0 0 8}$ & $\mathbf{2 0 0 9}$ & $\mathbf{2 0 1 0}$ & $\mathbf{2 0 1 1}$ \\
\hline CT & Soybean & Soybean/Rice & Soybean/Maize & Soybean \\
\hline NT1 & Soybean & Soybean/Ruziziensis & Soybean/Ruziziensis & Soybean \\
\hline NT2 & Soybean & Soybean/'Piatã' & Soybean/'Piatã' & Soybean \\
\hline NT3 & Soybean & Soybean/'Massai' & Soybean/'Massai' & Soybean \\
\hline
\end{tabular}

CT-Conventional tillage, NT1, No-till in succession with Urochloa ruziziensis/soybean, NT2, No-till in succession with Urochloa brizantha 'Piatã'/soybean, NT3No-till in succession with Panicum maximum 'Massai'/soybean.

\section{Sampling and physical and chemical characterization}

The plots measured 0.03 hectare $(30 \times 10 \mathrm{~m})$. To determine how Po fractionation varied at different depths, soils were collected at depths of 0-5, 5-10, and 10-20 cm in two times: first in December (2010) prior to planting and fertilizing for the soybean crop, and second collected in May (2011) and subsequently at harvest. Soil samples were collected using a stainless auger along the plant rows. Five samples were combined into a composite sample, summing four composite samples per plot and 16 composite samples per treatment.

The soil $\mathrm{pH}$ was measured in water using a soil:solution ratio of 1:2.5. Calcium and $\mathrm{Mg}$ were extracted with $1 \mathrm{~mol} \cdot \mathrm{L}^{-1} \mathrm{KCl}$ and determined using an atomic absorption spectrometry. Extractable K was extracted using the Mehlich-1 solution method and determined using a flame photometry. Available $\mathrm{P}$ was extracted using resin (van Raij et al. 1986) and Mehlich-1 solution $0.05 \mathrm{~mol} \cdot \mathrm{L}^{-1} \mathrm{HCl}$ and $0.0125 \mathrm{~mol} \cdot \mathrm{L}^{-1} \mathrm{H}_{2} \mathrm{SO}_{4}$ both quantified by colorimetry. Exchangeable $\mathrm{Al}\left(\mathrm{Al}^{3+}\right)$ was extracted with a $1 \mathrm{~mol} \cdot \mathrm{L}^{-1} \mathrm{KCl}$ solution and determined using titration with $0.025 \mathrm{~mol} \cdot \mathrm{L}^{-1} \mathrm{NaOH}$. The potential acidity $(\mathrm{H}+\mathrm{Al})$ was determined via extraction with $0.5 \mathrm{~mol} \cdot \mathrm{L}^{-1}$ calcium acetate at $\mathrm{pH} 7.0$ and quantified by titration with $0.025 \mathrm{~mol} \cdot \mathrm{L}^{-1} \mathrm{NaOH}$. Total cationic exchange capacity $\left(\mathrm{CEC} \mathrm{pH} \mathrm{7)} \mathrm{was} \mathrm{calculated} \mathrm{as} \mathrm{Ca}^{2+}+\mathrm{Mg}^{2+}+\mathrm{K}+\mathrm{H}+\mathrm{Al}\right.$; bases saturation $(\mathrm{V})=\left(\mathrm{Ca}^{2+}+\mathrm{Mg}^{2+}+\mathrm{K}\right) \times 100 / \mathrm{CEC}$; $\mathrm{Al}$ saturation $(\mathrm{m})=\mathrm{Al}^{3+} \times 100 /\left(\mathrm{Ca}^{2+}+\mathrm{Mg}^{2+}+\mathrm{K}^{+}+\mathrm{Al}^{3+}\right)$ and the organic matter content was estimated using the soil organic carbon concentration as measured by wet combustion $(\mathrm{OM}=\mathrm{OC} \times 1,724)$ (Donagema et al. 2011). Soil granulometric analysis was performed via the pipette method (Gee and Or 2002). Soil chemical and texture attributes are provided in Table 2.

\section{Phosphorus analysis}

Total $\mathrm{P}$ was determined from the acid digestion $\left(\mathrm{HNO}_{3}\right.$ and $\mathrm{HCl}$ concentrated in the ratio 3:1 in microwave according to the EPA 3051a method (Leytem 2009). Total organic P (total Po) was determined using the method of ignition, in which Po was converted by oxidation into inorganic $\mathrm{P}$ at a temperature of $550{ }^{\circ} \mathrm{C}$ and extracted by $1 \mathrm{~mol} \cdot \mathrm{L}^{-1} \mathrm{H}_{2} \mathrm{SO}_{4}$ which was determined by colorimetry (Kuo 1996).

Organic $\mathrm{P}$ was sequentially fractionated into the following pools by the respective extractants: labile Po, by $0.5 \mathrm{~mol} \cdot \mathrm{L}^{-1}$ $\mathrm{NaHCO}_{3}$ shaking for $16 \mathrm{~h}$; Po contained in biomass by $0.5 \mathrm{~mol} \cdot \mathrm{L}^{-1} \mathrm{NaHCO}_{3}$ with previous fumigation with $\mathrm{CHCl}_{3}$ shaking for $16 \mathrm{~h}$; moderately labile Po by $1 \mathrm{~mol} \cdot \mathrm{L}^{-1} \mathrm{HCl}$ shaking for $3 \mathrm{~h}$; Po bound to fulvic acid and Po bound to humic acid by $0.5 \mathrm{~mol} \cdot \mathrm{L}^{-1} \mathrm{NaOH}$ after shake $(6 \mathrm{~h})$ and acidification with $\mathrm{HCl}$; for nonlabile Po the solid residue was heated at $550{ }^{\circ} \mathrm{C}$ and extracted in $1 \mathrm{~mol} \cdot \mathrm{L}^{-1} \mathrm{H}_{2} \mathrm{SO}_{4}$ shaking for $1 \mathrm{~h}$ (Zhang and Kovar 2009).

For all extractions, an aliquot was taken for digestion with potassium persulfate for the determination of inorganic $\mathrm{P}(\mathrm{Pi})$. Thus, Po was determined as the difference between total P and Pi for each fraction. The analytical procedure described by 
Table 2. Soil attributes before the primary agricultural crop (2008).

\begin{tabular}{|c|c|c|c|c|c|c|c|c|c|c|c|c|c|c|}
\hline \multirow{2}{*}{ Depth } & \multirow{2}{*}{$\mathrm{pH}^{\mathrm{a}}$} & $\mathrm{OM}$ & $\mathbf{P}^{\mathrm{b}}$ & $\mathbf{P c}$ & $\mathrm{Al}^{3+}$ & $\mathrm{H}+\mathrm{Al}$ & $\mathrm{K}$ & $\mathrm{Ca}^{2+}$ & $\mathbf{M g}^{2+}$ & CEC & V & \multirow{2}{*}{$\begin{array}{l}\mathbf{m} \\
\%\end{array}$} & \multirow{2}{*}{$\begin{array}{r}\text { Sand } \\
\mathbf{g} \cdot 1\end{array}$} & \multirow{2}{*}{$\begin{array}{l}\text { Clay } \\
\text {-1 }^{-1}\end{array}$} \\
\hline & & $\mathbf{g} \cdot \mathbf{k g}^{-1}$ & \multicolumn{2}{|c|}{$\mathbf{m g} \cdot \mathbf{k g}^{-1}$} & \multicolumn{7}{|c|}{$\mathrm{mmol}_{c} \cdot \mathbf{k g}^{-1}$} & & & \\
\hline \multicolumn{15}{|c|}{$\mathrm{NT} 1^{\mathrm{d}}$} \\
\hline $0-5 \mathrm{~cm}$ & 5.3 & 39.6 & 17.1 & 16.2 & 1.5 & 52.6 & 3.4 & 28.4 & 6.1 & 90.5 & 41.9 & 3.9 & 45 & 615 \\
\hline $5-10 \mathrm{~cm}$ & 5.0 & 29.0 & 13.5 & 13.3 & 2.7 & 50.5 & 1.1 & 18.2 & 11.0 & 80.8 & 37.5 & 8.1 & 43 & 638 \\
\hline $10-20 \mathrm{~cm}$ & 4.8 & 26.9 & 6.6 & 7.5 & 3.6 & 51.5 & 1.0 & 17.0 & 5.6 & 75.1 & 31.5 & 13.1 & 47 & 705 \\
\hline \multicolumn{15}{|c|}{$\mathrm{NT} 2^{\mathrm{e}}$} \\
\hline $0-5 \mathrm{~cm}$ & 5.4 & 43.4 & 17.4 & 15.2 & 1.1 & 49.5 & 4.5 & 33.2 & 13.6 & 100.8 & 50.9 & 2.2 & 43 & 570 \\
\hline $5-10 \mathrm{~cm}$ & 5.6 & 35.8 & 15.2 & 17.3 & 1.9 & 54.3 & 1.8 & 24.2 & 8.1 & 88.4 & 38.6 & 5.2 & 43 & 590 \\
\hline $10-20 \mathrm{~cm}$ & 5.1 & 32.1 & 13.5 & 8.1 & 1.4 & 52.7 & 1.5 & 23.8 & 5.1 & 83.1 & 36.6 & 4.4 & 41 & 670 \\
\hline \multicolumn{15}{|c|}{ NT3 ${ }^{f}$} \\
\hline $0-5 \mathrm{~cm}$ & 5.4 & 44.6 & 12.2 & 9.8 & 1.1 & 49.1 & 2.7 & 29.8 & 7.0 & 88.6 & 44.6 & 2.8 & 45 & 619 \\
\hline $5-10 \mathrm{~cm}$ & 5.3 & 36.7 & 9.9 & 16.4 & 1.9 & 57.1 & 1.4 & 27.5 & 6.1 & 92.1 & 38.0 & 5.2 & 46 & 610 \\
\hline $10-20 \mathrm{~cm}$ & 5.1 & 31.7 & 7.3 & 7.6 & 2.2 & 54.9 & 3.8 & 23.4 & 4.8 & 86.9 & 36.9 & 6.4 & 42 & 700 \\
\hline \multicolumn{15}{|c|}{$\mathrm{CT}^{\mathrm{g}}$} \\
\hline $0-5 \mathrm{~cm}$ & 5.6 & 44.1 & 11.4 & 14.1 & 1.4 & 56.3 & 4.0 & 36.3 & 10.0 & 106.6 & 47.2 & 2.7 & 47 & 600 \\
\hline $5-10 \mathrm{~cm}$ & 5.4 & 36.7 & 10.8 & 11.9 & 1.1 & 49.9 & 1.7 & 32.2 & 8.9 & 92.7 & 46.1 & 2.6 & 43 & 670 \\
\hline $10-20 \mathrm{~cm}$ & 5.2 & 36.4 & 8.1 & 7.2 & 2.0 & 45.3 & 1.5 & 26.1 & 8.2 & 81.1 & 44.1 & 5.4 & 38 & 690 \\
\hline \multicolumn{15}{|c|}{$N V^{h}$} \\
\hline $0-5 \mathrm{~cm}$ & 5.8 & 75.0 & 8.0 & 1.2 & 1.3 & 62.5 & 1.3 & 54.6 & 16.9 & 135.3 & 53.8 & 1.7 & 53 & 660 \\
\hline $5-10 \mathrm{~cm}$ & 5.2 & 52.6 & 10.6 & 0.6 & 2.8 & 58.5 & 0.8 & 23.0 & 8.0 & 90.3 & 35.2 & 8.1 & 49 & 667 \\
\hline $10-20 \mathrm{~cm}$ & 5.0 & 37.7 & 9.5 & 0.4 & 3.8 & 53.9 & 0.6 & 17.2 & 4.9 & 76.6 & 29.6 & 14.4 & 49 & 690 \\
\hline
\end{tabular}

${ }^{a} \mathrm{pH}$, Determined in water, ${ }^{\mathrm{b}} \mathrm{P}$, Extracted via Mehlich-1; ${ }^{\mathrm{c} P}$, Extracted via Resin; ${ }^{\mathrm{N}} \mathrm{NT} 1$ - No-till in succession with Urochloa ruziziensis/soybean; eNT2 - No-till in succession with Urochloa brizantha 'Piatã'/soybean; 'NT3 - No-till in succession with Panicum maximum 'Massai'/soybean; ${ }^{9} \mathrm{CT}$ - Conventional tillage; NV - fragment of native vegetation.

Zhang and Kovar (2009) was modified with the goal of extracting Pi from the fulvic acid and nonlabile organic P fractions (nonlabile Po), thereby avoiding an overestimate of Po values in these fractions. A new sequential extraction was performed to determine $\mathrm{Pi}$ in the acidified $\mathrm{NaOH}$ extract and to determine fulvic acid Po as the difference between $\mathrm{P}$ total and Pi. One sample of final residue of this extraction was subjected to incineration and other sample was not incinerated, this procedure was used to obtain the total nonlabile Po content as the difference between the incinerated and the nonincinerated samples.

\section{Statistical analysis}

All determinations were made in triplicate and the data were statistically treated in the R environment version 3.5.6 for Windows. The statistical procedure was performed differentiating samples of 0-5, 5-10, and 10-20 cm, comparing management systems and the two sampling periods. Analysis of variance was performed (ANOVA) as well as normality (Shapiro-Wilk) and variance homogeneity (Levene) tests. If homogeneity was observed, a least significant difference (LSD) was applied; and if there were no homogeneity, a Dunnett T3 as post hoc. Cluster and principal components analysis of phosphorus forms in the soils were performed considering all depths. All data were analyzed at a 95\% confidence level $(\mathrm{p}<0.05)$.

\section{RESULTS AND DISCUSSION}

The no-till systems (NT) showed higher levels of biomass $P$ than in the samples collected in conventional tillage (CT) after cultivation (Table 3). Specifically, the contents of the biomass $P$ fraction increased $(\mathrm{p}<0.05)$, at a depth of $0-5 \mathrm{~cm}$, in 
Table 3. Organic phosphorus fractions before (2010) and after soybean cultivation (2011) at varying depths under different soil management systems (conventional and no-tillage).

\begin{tabular}{|c|c|c|c|c|c|c|c|c|c|c|c|c|}
\hline \multirow{3}{*}{ Treatment } & \multicolumn{2}{|c|}{ Biomass $\mathrm{P} \pi$} & \multicolumn{2}{|c|}{ Labile $\mathrm{Po}^{\beta}$} & \multicolumn{2}{|c|}{ Mod. Iabile $\mathbf{P o}^{\alpha}$} & \multicolumn{2}{|c|}{ Fulvic Po $\gamma$} & \multicolumn{2}{|c|}{ Humic $\mathbf{P o}^{\varphi}$} & \multicolumn{2}{|c|}{ Nonlabile $\mathrm{Po}^{\theta}$} \\
\hline & Before & After & Before & After & Before & After & Before & After & Before & After & Before & After \\
\hline & \multicolumn{12}{|c|}{$\mathbf{m g} \cdot \mathbf{k g}^{-1}$} \\
\hline & \multicolumn{12}{|c|}{$0-5 \mathrm{~cm}$} \\
\hline$N V^{\star} \star$ & 22 & 19 & 37 & 40 & 20 & 13 & 50 & 53 & 38 & 20 & 146 & 231 \\
\hline $\mathrm{NT} 1^{\mathrm{b}}$ & $17 \mathrm{aB}$ & $25 \mathrm{aA}$ & $15 \mathrm{bB}$ & $34 \mathrm{bA}$ & $16 \mathrm{bA}$ & $9 \mathrm{bB}$ & $51 \mathrm{aB}$ & $71 \mathrm{aA}$ & $38 \mathrm{aB}$ & $50 \mathrm{aA}$ & 132 bB & $189 \mathrm{aA}$ \\
\hline $\mathrm{NT} 2^{\mathrm{c}}$ & $17 \mathrm{aA}$ & $20 \mathrm{aA}$ & $28 \mathrm{aB}$ & $41 \mathrm{aA}$ & $29 \mathrm{aA}$ & $13 \mathrm{aB}$ & $45 \mathrm{aA}$ & $49 \mathrm{bA}$ & $30 \mathrm{bA}$ & $35 \mathrm{aA}$ & $140 \mathrm{bB}$ & $184 \mathrm{aA}$ \\
\hline $\mathrm{NT}^{\mathrm{d}}$ & $16 \mathrm{aB}$ & $27 \mathrm{aA}$ & $15 \mathrm{bB}$ & $23 \mathrm{cA}$ & $25 \mathrm{aA}$ & $11 \mathrm{abB}$ & $49 \mathrm{aA}$ & $55 \mathrm{abA}$ & $16 \mathrm{cB}$ & $43 \mathrm{aA}$ & 175 bA & $165 \mathrm{aA}$ \\
\hline $\mathrm{CT}^{\mathrm{e}}$ & $17 \mathrm{aA}$ & $10 \mathrm{bA}$ & $28 \mathrm{aA}$ & $24 \mathrm{cB}$ & $25 \mathrm{aA}$ & $13 \mathrm{aB}$ & $47 \mathrm{aA}$ & $46 \mathrm{bA}$ & $13 \mathrm{~dB}$ & 39 aA & $192 \mathrm{aB}$ & $206 \mathrm{aA}$ \\
\hline \multirow[t]{2}{*}{$\mathrm{CV}^{f}(\%)$} & 15 & 29 & 8 & 4 & 14 & 15 & 23 & 20 & 6 & 24 & 16 & 16 \\
\hline & \multicolumn{12}{|c|}{$5-10 \mathrm{~cm}$} \\
\hline NV & 13 & 9 & 26 & 20 & 29 & 5 & 45 & 43 & 24 & 16 & 178 & 200 \\
\hline NT1 & $13 \mathrm{aB}$ & $22 \mathrm{aA}$ & $20 \mathrm{aB}$ & $28 \mathrm{bA}$ & $12 \mathrm{cA}$ & $14 \mathrm{bA}$ & $59 \mathrm{aA}$ & $51 \mathrm{aA}$ & $36 \mathrm{aA}$ & $33 \mathrm{aA}$ & $147 \mathrm{aB}$ & $232 \mathrm{aA}$ \\
\hline NT2 & $9 \mathrm{aB}$ & $18 \mathrm{abA}$ & $24 \mathrm{bB}$ & $33 \mathrm{aA}$ & $20 \mathrm{bA}$ & $10 \mathrm{cB}$ & $47 \mathrm{aB}$ & $65 \mathrm{aA}$ & $29 \mathrm{bA}$ & $18 \mathrm{bB}$ & $153 \mathrm{aB}$ & $229 \mathrm{abA}$ \\
\hline NT3 & $12 \mathrm{aA}$ & $16 \mathrm{bA}$ & $15 \mathrm{cB}$ & $31 \mathrm{aA}$ & $29 a A$ & $17 \mathrm{aB}$ & $54 \mathrm{aA}$ & $48 \mathrm{aA}$ & $14 \mathrm{cA}$ & $17 \mathrm{bcA}$ & $132 \mathrm{aB}$ & $207 \mathrm{bA}$ \\
\hline $\mathrm{CT}$ & $13 \mathrm{aA}$ & $8 \mathrm{cA}$ & $15 \mathrm{cB}$ & $22 \mathrm{cA}$ & $4 \mathrm{~dB}$ & $7 \mathrm{dA}$ & $36 \mathrm{aA}$ & $45 \mathrm{aA}$ & $6 \mathrm{~dB}$ & $15 \mathrm{bcA}$ & $175 \mathrm{aB}$ & $221 \mathrm{abA}$ \\
\hline \multirow[t]{2}{*}{ CV (\%) } & 30 & 24 & 6 & 5 & 6 & 18 & 31 & 14 & 12 & 19 & 21 & 10 \\
\hline & \multicolumn{12}{|c|}{$10-20 \mathrm{~cm}$} \\
\hline NV & 3 & 6 & 17 & 22 & 4 & 6 & 30 & 34 & 7 & 13 & 199 & 221 \\
\hline NT1 & $7 \mathrm{abA}$ & $7 \mathrm{bA}$ & $19 \mathrm{bA}$ & $8 \mathrm{cB}$ & $15 \mathrm{bA}$ & $6 \mathrm{cB}$ & $39 a A$ & $43 \mathrm{bA}$ & $21 \mathrm{aA}$ & $8 \mathrm{bB}$ & $172 \mathrm{aB}$ & $254 \mathrm{abA}$ \\
\hline NT2 & $10 \mathrm{aB}$ & $20 \mathrm{aA}$ & $24 \mathrm{aB}$ & 36 aA & $4 \mathrm{cB}$ & $15 \mathrm{aA}$ & $40 \mathrm{aA}$ & $38 \mathrm{bcA}$ & $10 \mathrm{cA}$ & $10 \mathrm{aA}$ & $174 \mathrm{aB}$ & $229 \mathrm{abA}$ \\
\hline NT3 & $3 \mathrm{cA}$ & $7 \mathrm{bA}$ & $20 \mathrm{bA}$ & $9 \mathrm{cB}$ & $17 \mathrm{bA}$ & $10 \mathrm{bB}$ & $40 \mathrm{aA}$ & $33 \mathrm{bcA}$ & $14 \mathrm{bA}$ & $14 \mathrm{aA}$ & $157 \mathrm{aB}$ & $216 \mathrm{bA}$ \\
\hline $\mathrm{CT}$ & $5 \mathrm{bcA}$ & $5 \mathrm{bA}$ & $25 \mathrm{aA}$ & $24 \mathrm{bA}$ & $21 \mathrm{aA}$ & $6 \mathrm{cB}$ & $39 a B$ & $62 \mathrm{aA}$ & $6 \mathrm{~dB}$ & $12 \mathrm{aA}$ & $115 \mathrm{bB}$ & $265 \mathrm{aA}$ \\
\hline CV (\%) & 36 & 68 & 5 & 7 & 16 & 14 & 23 & 36 & 17 & 30 & 10 & 11 \\
\hline
\end{tabular}

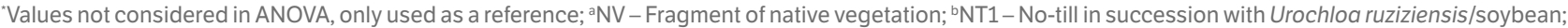

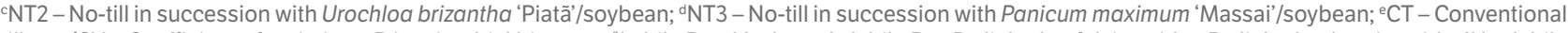
tillage; ' $\mathrm{CV}$ - Coefficient of variation. ${ }^{\pi P}$ in microbial biomass; ${ }^{\beta}$ Labile Po; ${ }^{\alpha}$ Moderately labile Po; ${ }^{\gamma}$ Po linked to fulvic acids; ${ }^{\varphi} P o$ linked to humic acids; ${ }^{\ominus}$ Nonlabile Po. Within each $P$ fraction, means followed by the same uppercase letter in a row (years) and lowercase letter in a column (tillage systems) are not significantly different $(p \leq 0.05)$ according to LSD test.

the NT1 (no-till in succession with U. ruziziensis) and NT3 (no-till in succession with Panicum maximum 'Massai') systems, compared to the first sampling period (Table 3).

The microbial biomass is very dynamic to the $\mathrm{P}$ immobilization from the soil solution when its availability in the system is high and when it is gradually released as microorganisms die (Bünemann 2015). It is possible that these NT management systems increased biological activity in the surface layer and consequently increased biomass $\mathrm{P}$ content. The increase in biomass $\mathrm{P}$ may be associated with the breakdown of organic matter or by the specific mineralization of organic phosphate through the actions of phosphatase-type exoenzymes (McGill and Cole 1981). According to Pacheco et al. (2013), U. ruziziensis straw has shorter permanence when compared to U. Brizantha. An increase in the decomposition rates and the release of nutrients in the soil can stimulate of soil microbial biomass probably due to stimulation of biological activity promoted by cultivation of soybeans and the humidity and temperature conditions found in no-till systems (Costa et al. 2015).

The NT system was more efficient than the CT treatment at promoting the accumulation of $\mathrm{P}$ biomass. Even in deeper soil layers, the NT system provides a higher supply of $\mathrm{P}$ to soils over longer periods than the other systems. Alterations in the distribution of the organic $\mathrm{P}$ formed in soils depend on the quantity of $\mathrm{P}$ exported during harvests, on soil preparation techniques, and on the ability of plants to access reserves of less labile forms of $\mathrm{P}$ (Damon et al. 2014). 
Levels of labile Po in the soil samples from all layers of the NT2 treatment increased significantly after soybean crop. However, the levels of labile Po declined in the soil surface layer of the CT system (Table 3), which suggests that labile Po was consumed due to its high accessibility to the plants. The labile Po fraction reached a maximum of $12 \%$ of total Po in the surface layer of the NV and NT2 systems (Fig. S1).

The labile Po fraction is generally very changed in soils mainly when tillage systems to soil conservation such as no-till were applied generating an accumulation of $\mathrm{P}$ forms. As observed with the biomass $\mathrm{P}$ values, the decomposition of crop residue and the accumulation of organic residues stimulate microbial activity, thus favoring the accumulation of organic $\mathrm{P}$ in the upper layers of the soil (Sharpley and Smith 1985). On the other hand, conventional tillage systems expose the soil adsorption sites and increase the contact between ions $\mathrm{P}$ and soil colloids, thus increasing the fixation, especially in outer sphere complexes and subsequently for inner sphere complexes (Fink et al. 2014).

The concentration of labile Po decreased with increasing depth, particularly in the native area, as also observed by Dieter et al. (2010), who observed similar reduction by evaluating the Pi and Po extracted by $0.5 \mathrm{~mol} \cdot \mathrm{L}^{-1} \mathrm{NaHCO}_{3}$ (equivalent to labile P). Amazonian soils in forested areas have low $\mathrm{P}$ levels and the main source for biomass decomposition is litter on the soil surface, so that the labile fraction of the Po considerably reduces with depth (Quesada et al. 2011).

All treatments showed declines in moderately labile Po levels superficially (0 to $5 \mathrm{~cm}$ layer) (Table 3, Fig. S1). The moderately labile Po fraction is highly soluble and reactive with the crystalline and low-crystalline forms of Fe and $\mathrm{Al}$, generating an accumulation trend similar to the nonlabile fraction (Gérard 2016). Roots can also induce high phosphatase activity in the rhizosphere, which increases the amount of $\mathrm{P}$ available to plants via less available forms like moderately labile (Celi and Barberis 2005).

The Po fraction bonded to fulvic acids showed larger changes as a function of cultivation time in the 0 to $5 \mathrm{~cm}$ layer. Among tillage systems, only the NT1 system stored more of this fraction than the CT system in the 0 to $5 \mathrm{~cm}$ layer (Table 3 ). Moreover, fulvic organic P levels tended to increase in the 10 to $20 \mathrm{~cm}$ layer of the CT system after cultivation.

The highest values of Po bound to fulvic acid between N1 and CT reflect an improvement in protecting the soil using previous ground cover plants Urochloa ruziziensis has a prostrate growth that quickly covers the soil surface, as well as a stem that lasts a long time in the soil due to a high $\mathrm{C} / \mathrm{N}$ ratio. This phenomenon may explain why the fulvic acid remained in the surface layer (Silva and Mendonça 2007). The Urochloa ruziziensis species has been used to avoid the effects of erosion and soil washing in newly established pastures and is also highly recommended for no-tillage methods, cover crops formation, and soil protection (Pariz et al. 2010). However, at deeper layer CT accumulate more of this fraction because fulvic acid is a humic substance with high total acidity, is soluble at all $\mathrm{pH}$ levels and can migrate to greater depths (Gonet et al. 2008). Therefore, the solubility of the fulvic Po fraction suggests that, when soils are unprotected, rainfall promotes its accumulation at greater depths. In the case of soil conservation tillage systems such as NT, however, the fraction tends to accumulate in the surface layer.

At a depth of 0 to $5 \mathrm{~cm}$ in both conventional and the no-till systems, levels of Po bonded to humic acids increased (Table 3). The Po bonded to humic acids is a stable fraction important to maintenance of organic matter in the soil, but in quantitative terms, the nonlabile Po fraction was more important than the other organic fractions at all depths studied (Table 3).

The patterns of humic Po observed in the systems highlight the stability of this fraction that tends to accumulate in the soil when there is entry of organic matter, so that in soils of the wet tropical region, humic acids become an important reserve of quickly available Po (He et al. 2011; Quesada et al. 2011). Other important source observed in large portion in this study, the nonlabile Po can assist with maintaining labile P fractions, and all P fractions may be available in the short, medium and long term, suggesting that much of the P applied as fertilizer or OM can be recovered (Guo et al. 2000). In highly weathered soils such as oxisols, which have high levels of iron and aluminum oxides, the OM levels can be a key to recovery P retained in the soil (Guedes et al. 2016).

The lower total P levels in the deeper layer of the soil in the NV (Table 4) are due to low P inputs to layer and the low mobility of $\mathrm{P}$ compared to the others systems studied. In forest soils, the nutrient source is mainly supplied by cycling organic materials on the soil surface, unlike other treatments that received phosphate fertilizer during the growing seasons of each year. The variations in levels of total $\mathrm{P}$ are smaller than the variations in labile, and this behavior is not reflected in the availability of labile fractions (Pavinato et al. 2010). 
Table 4. Contents of total $\mathrm{P}$, total organic $\mathrm{P}$ (total $\mathrm{Po}$ ) before soybean planting and after planting at different depths of samples from an oxisol under different management systems.

\begin{tabular}{|c|c|c|c|c|}
\hline \multirow{3}{*}{ Treatment } & \multicolumn{2}{|c|}{ Total P } & \multicolumn{2}{|c|}{ Total Po } \\
\hline & Before & After & Before & After \\
\hline & \multicolumn{4}{|c|}{$\mathbf{m g} \cdot \mathbf{k g}^{-1}$} \\
\hline & \multicolumn{4}{|c|}{$0-5 \mathrm{~cm}$} \\
\hline $\mathrm{NV}^{*}$ & 638 & 703 & 304 & 365 \\
\hline $\mathrm{NT} 1^{\mathrm{b}}$ & $644 \mathrm{bA}$ & $701 \mathrm{aA}$ & $261 \mathrm{bB}$ & $367 \mathrm{aA}$ \\
\hline $\mathrm{NT} 2^{\mathrm{c}}$ & 583 bB & 793 aA & 280 bB & 332 bA \\
\hline $\mathrm{NT}^{\mathrm{d}}$ & $474 \mathrm{cB}$ & $701 \mathrm{aA}$ & $287 \mathrm{bB}$ & $341 \mathrm{abA}$ \\
\hline $\mathrm{CT}^{\mathrm{e}}$ & $751 \mathrm{aA}$ & $778 \mathrm{aA}$ & $312 \mathrm{aA}$ & $319 \mathrm{bA}$ \\
\hline \multirow[t]{2}{*}{$\mathrm{CV}^{\mathrm{f}}(\%)$} & 8 & 8 & 13 & 12 \\
\hline & \multicolumn{4}{|c|}{$5-10 \mathrm{~cm}$} \\
\hline NV & 670 & 668 & 309 & 287 \\
\hline NT1 & $613 \mathrm{aA}$ & $675 a b A$ & $281 \mathrm{aB}$ & $372 \mathrm{aA}$ \\
\hline NT2 & $569 \mathrm{aB}$ & 657 bA & 276 abB & 366 aA \\
\hline NT3 & $572 \mathrm{aB}$ & 728 aA & 251 bB & 329 abA \\
\hline $\mathrm{CT}$ & 598 aA & 637 bA & 244 bB & 312 bB \\
\hline \multirow[t]{2}{*}{ CV (\%) } & 10 & 6 & 19 & 15 \\
\hline & \multicolumn{4}{|c|}{$10-20 \mathrm{~cm}$} \\
\hline NV & 324 & 320 & 256 & 297 \\
\hline NT1 & $562 \mathrm{aA}$ & $571 \mathrm{aA}$ & 269 aA & 321 bA \\
\hline NT2 & $532 \mathrm{aA}$ & $511 \mathrm{aA}$ & 249 aA & $343 a b A$ \\
\hline NT3 & 493 aA & 589 aA & $247 a A$ & $285 \mathrm{cA}$ \\
\hline $\mathrm{CT}$ & $501 \mathrm{aA}$ & $542 \mathrm{aA}$ & 208 bB & $368 \mathrm{abA}$ \\
\hline CV (\%) & 19 & 11 & 31 & 35 \\
\hline
\end{tabular}

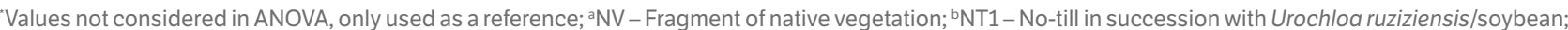
cNT2 - No-till in succession with Urochloa brizantha 'Piatä'/soybean; 'NT3 - No-till in succession with Panicum maximum 'Massai'/soybean; ${ }^{\text {eCT }}$ - Conventional tillage; ${ }^{\prime} \mathrm{CV}$ - Coefficient of variation. Within each P fraction, means followed by the same uppercase letter in a row (years) and lowercase letter in a column (tillage systems) are not significantly different $(p \leq 0.05)$ according to the LSD test.

With principal components analysis, it was possible to extract two components (PC1 and PC2), which explained $60 \%$ of the data variance (Table S1). The NT3 treatment was strongly correlated - above 0.70, according to Manly (1994) - with the values of $\mathrm{m} \%, \mathrm{Al}^{3+}$ and $\mathrm{H}+\mathrm{Al}$ in PC1 (Table S1 and Fig. 1). These attributes were observed in greater proportion in NT3 and CT treatments.

The NT2 treatment have a higher contribution of the variables related to soil fertility, such as exchangeable bases, CEC, as well as $\mathrm{pH}$ and labile Po fraction. However, for NT1 and NT2 a higher contribution of available P levels was observed (extracted by resin and Mehlich-1), Total P, biomass P, labile Po, and moderately labile Po (Table S1, Fig. 1). Thus, NT2 supplied greater quantity of the main Po fractions to soil in relation to other treatments, showing also one of the higher fertility levels. Figure 1 shows that most of the Po fractions were dependent on the available P levels as well as levels of $\mathrm{m}, \mathrm{Al}^{3+}$ and potential acidity.

Cluster analysis (Fig. 2) shows that CT and NT1 treatments showed a higher level of similarity in relation to variables considered in the PCA, while NV showed greater dissimilarity due to lower P levels found in this soil.

The fractions obtained from the phosphorus fractionation scheme and fertility analysis were used to perform cluster and principal component analysis (PCA) in order to summarize information referring to set of variables and responses obtained in the experiment. Phosphorus and $\mathrm{Al}^{3+}$ levels in the soil are often related to acidity levels, which in Amazonian soils becomes a critical factor for the $\mathrm{P}$ fertilization management. The high soil acidity reduces $\mathrm{P}$ availability, promoting the increase of less labile $\mathrm{P}$ fractions due to protonation in the colloidal surface, stimulating retention of inorganic and organic P forms (Barrow et al. 2015). 


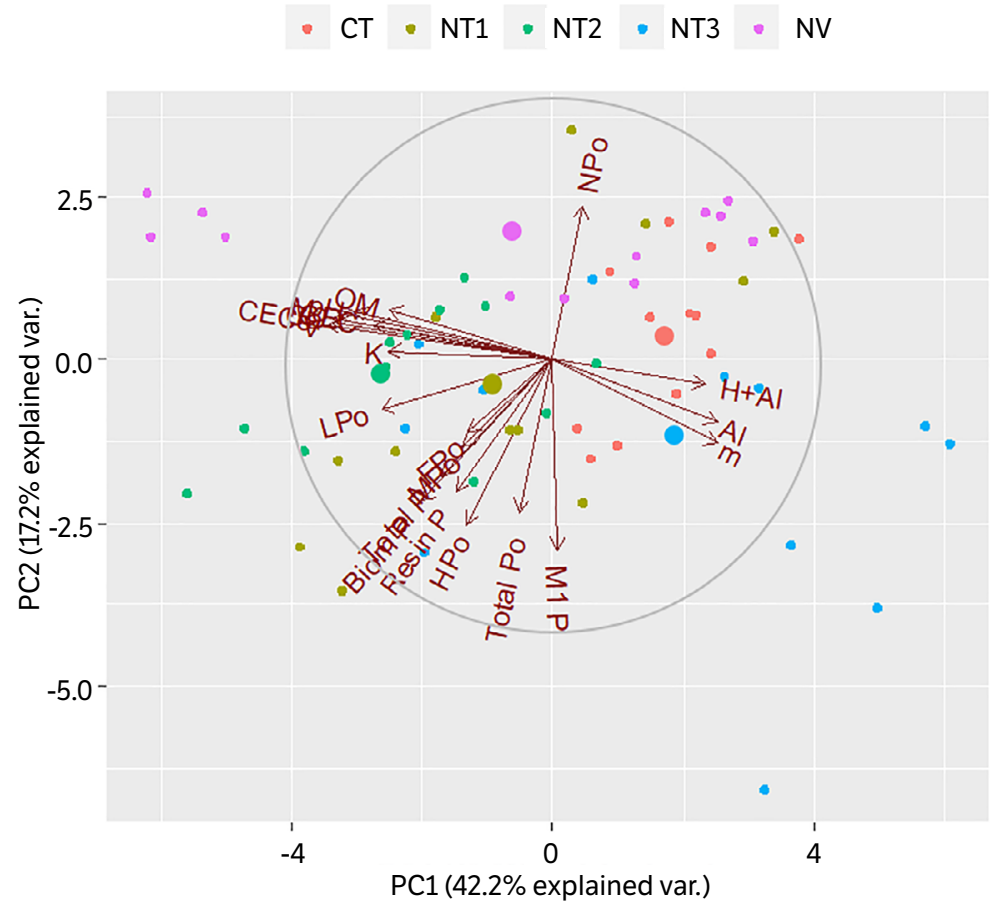

Figure 1. Principal component analysis biplot for treatments considering all depths: NT1 - No-till in succession with Urochloa ruziziensis/soybean; NT2 - No-till in succession with Urochloa brizantha 'Piatã'/soybean; NT3 - No-till in succession with Panicum maximum 'Massai'/soybean; CT - Conventional tillage; NV - Fragment of native vegetation. Highlighted points represent the average of treatments.

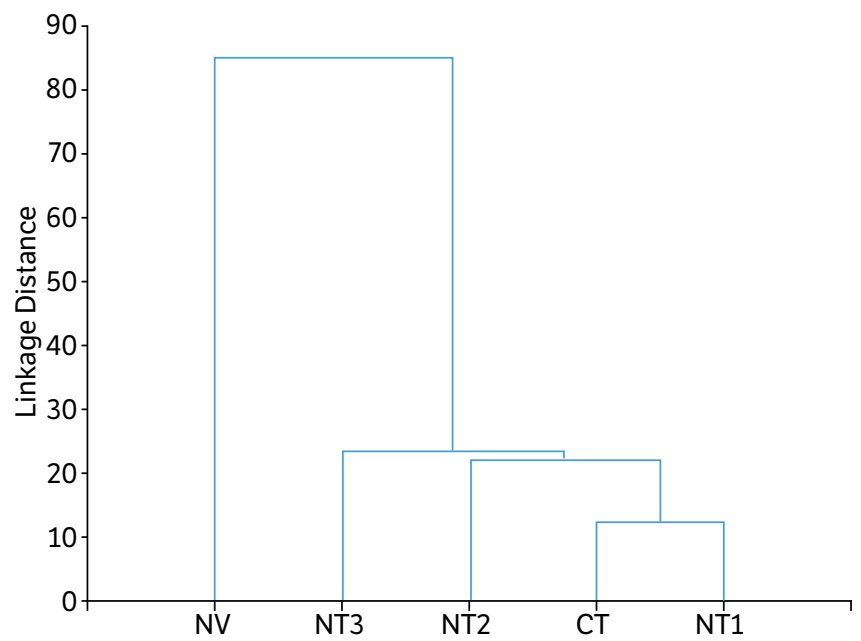

Figure 2. Cluster analysis for treatments considering all depths: NT1-No-till in succession with Urochloa ruziziensis/soybean; NT2 - No-till in succession with Urochloa brizantha 'Piatã'/soybean; NT3 - No-till in succession with Panicum maximum 'Massai'/soybean; CT - Conventional tillage; NV - Fragment of native vegetation.

\section{CONCLUSION}

The distribution of organic $P$ fractions varied between tillage systems, mainly in the surface soil layer, but did not alter the total P. Furthermore, the humic Po, fulvic Po, and nonlabile Po fractions were more expressive than the other organic fractions.

Among the evaluated systems, the tillage system using the Urochloa brizantha 'Piatã' (NT2) excels in providing increased the most of organic $\mathrm{P}$ fractions being considered the best alternative to cover crops formation and supply Po among the species tested. The use of this forage in no-tillage cultivation in Amazon region can be important for soil management. 


\section{FUNDERS}

Conselho Nacional de Desenvolvimento Científico e Tecnológico

[http://doi.org/10.13039/501100003593]

\section{AUTHOR'S CONTRIBUTION}

Conceptualization, Alves L. W. R., Correia B. L. and Ramos, S. J.; Methodology, Guedes R. S.; Writing - Original Draft, Guedes R. S.; Writing - Review \& Editing, Alves L. W. R., Correia B. L. and Ramos, S. J.; Data curation, Alleoni, L. R. F. and Fernandes A. R.; Validation, Alleoni, L. R. F. and Fernandes A. R.; Funding acquisition, Alleoni, L. R. F. and Fernandes A. R.; Supervision, Alleoni, L. R. F. and Fernandes A. R.

\section{REFERENCES}

Barrow, N. J., Feng, X. H. and Yan, Y. P. (2015). The specific adsorption of organic and inorganic phosphates by variable-charge oxides. European Journal of Soil Science, 66, 859-866. https://doi.org/10.1111/ejss.12280

Bünemann, E. K. (2015). Assessment of gross and net mineralization rates of soil organic phosphorus - A review. Soil Biology and Biochemistry, 89, 82-98. http://doi.org/10.1016/j.soilbio.2015.06.026

Celi, L. and Barberis, E. (2005). Abiotic stabilization of organic phosphorus in the environment. In B. L. Turner, E. Frossard and D. S. Baldwin (Eds.), Organic phosphorus in the environment (p. 113-132). Oxford: Oxford University Press. https://doi.org/10.1079/9780851998220.0113 Costa, N. R., Andreotti, M., Lopes, K. S. M., Yokobatake, K. L., Ferreira, J. P., Pariz, C. M., Bonini, C. S. B. and Longhini, V. Z. (2015). Atributos do solo e acúmulo de carbono na integração lavoura-pecuária em sistema plantio direto. Revista Brasileira de Ciência do Solo, 39, 852863. https://doi.org/10.1590/01000683rbcs20140269

Damon, P. M., Bowden, B., Rose, T. and Rengel, Z. (2014). Crop residue contributions to phosphorus pools in agricultural soils: A review. Soil Biology and Biochemistry, 74, 127-137. https://doi.org/10.1016/j.soilbio.2014.03.003

Dan, H. A., Barroso, A. L. L., Dan, L. G. M., Procópio, S. O., Oliveira Junior, R. S., Constantin, J. and Feldkircher, C. (2011). Supressão imposta pelo mesotrione a Brachiaria brizantha em sistema de integração lavoura-pecuária. Planta Daninha, 29, 861-867. https://doi. org/10.1590/S0100-83582011000400016

Dias, D. G., Pegoraro, R. F., Alves, D. D., Porto, E. M. V., Santos Neto, J. A. and Aspiazú, I. (2015). Produção do capim Piatã submetido a diferentes fontes de fósforo. Revista Brasileira de Engenharia Agrícola e Ambiental, 19, 330-335. https://doi.org/10.1590/1807-1929/ agriambi.v19n4p330-335

Dieter, D., Elsenbeer, H. and Turner, B. L. (2010). Phosphorus fractionation in lowland tropical rainforest soils in central Panama. CATENA, 82, 118-125. https://doi.org/10.1016/j.catena.2010.05.010

Donagema, G. K., Campos, D. V. B., Calderano, S. B., Teixeira, W. G. and Viana, J. H. M. (2011). Manual de métodos de análise de solo [Documentos 132]. Rio de Janeiro: Embrapa solos.

Ferreira, A. C. B., Lamas, F. M., Carvalho, M. C. S., Salton, J. C. and Suassuna, N. D. (2010). Produção de biomassa por cultivos de cobertura do solo e produtividade do algodoeiro em plantio direto. Pesquisa Agropecuária Brasileira, 45, 546-553. https://doi.org/10.1590/ S0100-204X2010000600003 
Fink, J. R., Inda, A. V., Bayer, C., Torrent, J. and Barrón, V. (2014). Mineralogy and phosphorus adsorption in soils of south and central-west Brazil under conventional and no-tillage systems. Acta Scientiarum. Agronomy, 36, 379-387. https://doi.org/10.4025/actasciagron.v36i3.17937

Gee, G. W. and Or, D. (2002). 2.4 Particle-Size Analysis. In J. H. Dane and G. C. Toop (Eds.), Methods of Soil Analysis: Part 4 Physical Methods, 5.4 (p. 255-293). Hoboken: John Wiley \& Sons. https://doi.org/10.2136/sssabookser5.4.c12

Gérard, F. (2016). Clay minerals, iron/aluminum oxides and their contribution to phosphate sorption in soils - A myth revisited. Geoderma, 262, 213-226. https://doi.org/10.1016/j.geoderma.2015.08.036

Gonet, S. S., Debska, B., Zaujec, A. and Banach-Szott, M. (2008). Properties of humus of natural forest soil and arable soil. Ekológia (Bratislava), 27, 351-366.

Guedes, R. S., Melo, L. C. A., Vergütz, L., Rodríguez-Vila, A., Covelo, E. F. and Fernandes, A. R. (2016). Adsorption and desorption kinetics and phosphorus hysteresis in highly weathered soil by stirred flow chamber experiments. Soil and Tillage Research, 162, 46-54. https:// doi.org/10.1016/j.still.2016.04.018

Guo, F., Yost, R. S., Hue, N. V., Evensen, C. I. and Silva, J. A. (2000). Changes in phosphorus fractions in soils under intensive plant growth. Soil Science Society of America Journal, 64, 1681-1689. https://doi.org/10.2136/sssaj2000.6451681x

He, Z., Olk, D. C. and Cade-Menun, B. J. (2011). Forms and lability of phosphorus in humic acid fractions of hord silt loam soil. Soil Science Society of America Journal, 75, 1712-1722. https://doi.org/10.2136/sssaj2010.0355

Jin, X., Wang, S., Pang, Y. and Wu, F. W. (2006). Phosphorus fractions and the effect of pH on the phosphorus release of the sediments from different trophic areas in Taihu Lake, China. Environmental Pollution, 139, 288-295. https://doi.org/10.1016/j.envpol.2005.05.010

Kuo, S. (1996). Phosphorus. In D. L. Sparks, A. L. Page, P. A. Helmke, R. H. Loeppert, P. N. Soltanpour, M. A. Tabatabai, C. T. Johnston and M. E. Sumner (Ed.), Methods of soil analysis: Part 3 Chemical methods, 5.3. (p. 869-919). Hoboken: John Wiley \& Sons. https://doi. org/10.2136/sssabookser5.3.c32

Leithold, G., Hülsbergen, K.-J. and Brock, C. (2015). Organic matter returns to soils must be higher under organic compared to conventional farming. Journal of Plant Nutrition and Soil Science, 178, 4-12. https://doi.org/10.1002/jpln.201400133

Leytem, A. (2009). Total phosphorus in soil. In J. L. Kovar and G. M. Pierzynski (Eds.), Methods of phosphorus analysis for soils, sediments, residuals and waters (p. 44-49). Blacksburg: Virginia Tech University.

Manly, B. F. J. (1994). Multivariate statistical methods: a primer. New York: Chapman \& Hall.

McGill, W. B. and Cole, C. V. (1981). Comparative aspects of cycling of organic C, N, S and P through soil organic matter. Geoderma, 26, 267-286. https://doi.org/10.1016/0016-7061(81)90024-0

Pacheco, L. P., Monteiro, M. M. S., Silva, R. F., Soares, L. S., Fonseca, W. L., Nóbrega, J. C. A., Petter, F. A., Alcântara Neto, F. and Osajima, J. A. (2013). Produção de fitomassa e acúmulo de nutrientes por plantas de cobertura no cerrado piauiense. Bragantia, 72, $237-246$. https://doi.org/10.1590/brag.2013.041

Pariz, C. M., Ferreira, R. L., Sá, M. E., Andreotti, M., Chioderoli, C. A. and Ribeiro, A. P. (2010). Qualidade fisiológica de sementes de Brachiaria e avaliação da produtividade de massa seca, em diferentes sistemas de integração lavoura-pecuária sob irrigação. Pesquisa Agropecuária Tropical, 40, 330-340. https://doi.org/10.5216/pat.v40i3.6590

Pavinato, P. S., Dao, T. H. and Rosolem, C. A. (2010). Tillage and phosphorus management effects on enzyme-labile bioactive phosphorus availability in Cerrado Oxisols. Geoderma, 156, 207-215. https://doi.org/10.1016/j.geoderma.2010.02.019

Quesada, C. A., Lloyd, J., Anderson, L. O., Fyllas, N. M., Schwarz, M. and Czimczik, C. I. (2011). Soils of Amazonia with particular reference to the RAINFOR sites. Biogeosciences, 8, 1415-1440. https://doi.org/10.5194/bg-8-1415-2011 
Redel, Y. D., Rubio, R., Rouanet, J. L. and Borie, F. (2007). Phosphorus bioavailability affected by tillage and crop rotation on a Chilean volcanic derived Ultisol. Geoderma, 139, 388-396. https://doi.org/10.1016/j.geoderma.2007.02.018

Rheinheimer, D. S., Fornari, M. R., Bastos, M. C., Fernandes, G., Santanna, M. A., Calegari, A., Canalli, L. B. S., Caner, L., Labanowski, J. and Tiecher, T. (2019). Phosphorus distribution after three decades of different soil management and cover crops in subtropical region. Soil and Tillage Research, 192, 33-41. https://doi.org/10.1016/j.still.2019.04.018

Rodrigues, M., Pavinato, P. S., Withers, P. J. A., Teles, A. P. B. and Herrera, W. F. B. (2016). Legacy phosphorus and no tillage agriculture in tropical oxisols of the Brazilian savanna. Science of The Total Environment, 542, 1050-1061. https://doi.org/10.1016/j.scitotenv.2015.08.118

Rodrigues, T. E., Silva, R. C., Silva, J. M. L., Oliveira Junior, R. C., Gama, J. R. N. F. and Valente, M. A. (2003). Caracterização e classificação dos solos do município de Paragominas, Estado do Pará [Documento 162]. Belém, PA: Embrapa Amazônia Oriental. [Accessed Apr. 17, 2020]. Available at: https://www.infoteca.cnptia.embrapa.br/bitstream/doc/408067/1/OrientalDoc162.PDF

Sá, J. C. M., Tivet, F., Lal, R., Briedis, C., Hartman, D. C., Santos, J. Z. and Santos, J. B. (2014). Long-term tillage systems impacts on soil C dynamics, soil resilience and agronomic productivity of a Brazilian Oxisol. Soil and Tillage Research, 136, 38-50. https://doi. org/10.1016/j.still.2013.09.010

Santos, H. G., Carvalho Júnior, W., Dart, R. O., Aglio, M. L. D., Sousa, J. S., Pares, J. G., Fontana, A., Martins, A. L. S. and Oliveira, A. P. (2011). O novo mapa de solos do Brasil: legenda atualizada [Documentos 130]. Rio de Janeiro: Embrapa Solos.

Sharpley, A. N. and Smith, S. J. (1985). Fractionation of inorganic and organic phosphorus in virgin and cultivated soils. Soil Science Society of America Journal, 49, 127-130. https://doi.org/10.2136/sssaj1985.03615995004900010025x

Silva, I. R. and Mendonça, E. S. (2007). Matéria orgânica do solo. In R. F. Novais, V. H. Alvarez, N. F. Barros, R. L. F. Fontes, R. B. Cantarutti and J. C. L. Neves (Eds.), Fertilidade do solo (p. 275-374). Viçosa: SBCS.

Soil Survey Staff. (2014). Keys to soil taxonomy, 12th ed. USDA-Natural Resources Conservation Service Washington, DC. [Accessed Apr. 17, 2020]. Available at: https://www.nrcs.usda.gov/wps/portal/nrcs/detail/soils/survey/class/?cid=nrcs142p2_053580

Tiecher, T., Santos, D. R., Kaminski, J. and Calegari, A. (2012). Forms of inorganic phosphorus in soil under different long term soil tillage systems and winter crops. Revista Brasileira de Ciência do Solo, 36, 271-281. https://doi.org/10.1590/S0100-06832012000100028

Valentim, J. F. and Moreira, P. (1994). Adaptação, produtividade, composição morfológica e distribuição estacional da produção de forragem de ecotipos de Panicum maximum no Acre [Boletim de Pesquisa 11]. Rio Branco: EMBRAPA-CPAF-AC.

Van Raij, B., Quaggio, J. A. and Silva, N. M. (1986). Extraction of phosphorus, potassium, calcium and magnesium from soils by an ion-exchange resin procedure. Communications in Soil Science and Plant Analysis, 17, 547-566. https://doi.org/10.1080/00103628609367733

Vincent, A. G., Turner, B. L. and Tanner, E. V. J. (2010). Soil organic phosphorus dynamics following perturbation of litter cycling in a tropical moist forest. European Journal of Soil Science, 61, 48-57. https://doi.org/10.1111/j.1365-2389.2009.01200.x

Wang, Y., Li, C., Tu, C., Hoyt, G. D., DeForest, J. L. and Hu, S. (2017). Long-term no-tillage and organic input management enhanced the diversity and stability of soil microbial community. Science of The Total Environment, 609, 341-347. https://doi.org/10.1016/j. scitotenv.2017.07.053

Zamuner, E. C., Picone, L. I. and Echeverria, H. E. (2008). Organic and inorganic phosphorus in Mollisol soil under different tillage practices. Soil and Tillage Research, 99, 131-138. https://doi.org/10.1016/j.still.2007.12.006

Zhang, H. and Kovar, J. L. (2009). Fractionation of soil phosphorus. In J. L. Kovar and G. M. Pierzynski (Eds.), Methods of phosphorus analysis for soils, sediments, residuals and waters (p. 50-60). Blacksburg: Virginia Tech University. 


\section{SUPPLEMENTARY FILE}

Table S1. Description of variance explained with factor loadings (unrotated) related to soils.

\begin{tabular}{|c|c|c|c|c|}
\hline Component & Eigenvalue & Total variance (\%) & Cumulative Eigenvalue & Cumulative (\%) \\
\hline 1 & 8.84 & 44.22 & 8.84 & 44.22 \\
\hline 2 & 3.25 & 15.23 & 12.09 & 59.45 \\
\hline \multirow{2}{*}{ Variables } & \multicolumn{2}{|c|}{ Factor Loadings } & & \\
\hline & Factor $1^{\star}$ & Factor $2^{\star}$ & & \\
\hline $\mathrm{pH}$ & -0.85 & 0.21 & & \\
\hline OM & -0.70 & 0.23 & & \\
\hline Resin $P$ & -0.40 & -0.55 & & \\
\hline M1P & 0.03 & -0.81 & & \\
\hline $\mathrm{H}+\mathrm{Al}$ & 0.65 & -0.08 & & \\
\hline $\mathrm{Al}$ & 0.70 & -0.23 & & \\
\hline $\mathrm{Mg}$ & -0.91 & -0.24 & & \\
\hline $\mathrm{K}$ & -0.70 & 0.01 & & \\
\hline $\mathrm{Ca}$ & -0.94 & 0.16 & & \\
\hline CEC & -0.76 & 0.16 & & \\
\hline CECe & -0.94 & -0.16 & & \\
\hline V & -0.96 & 0.13 & & \\
\hline $\mathrm{m}$ & 0.70 & -0.33 & & \\
\hline Total Po & -0.13 & -0.64 & & \\
\hline Total P & -0.47 & -0.51 & & \\
\hline Biom $\mathrm{P}$ & -0.54 & -0.59 & & \\
\hline LPo & -0.72 & -0.22 & & \\
\hline MPo & -0.38 & -0.31 & & \\
\hline HPo & -0.36 & -0.71 & & \\
\hline FPo & -0.36 & 0.31 & & \\
\hline NPo & 0.13 & 0.66 & & \\
\hline
\end{tabular}

*values > 0.70 (marked) are significant (Manly 1994) 

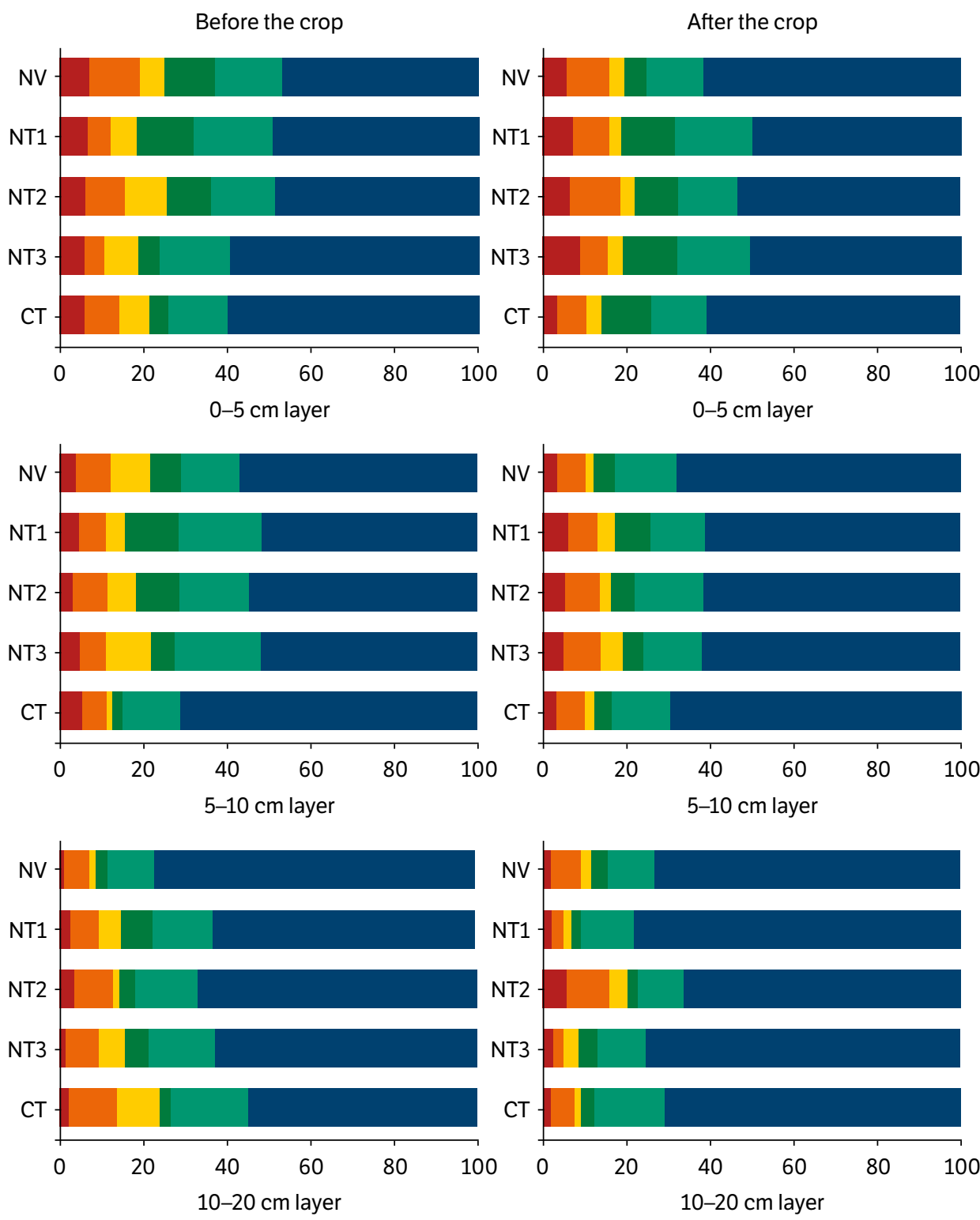

Biomass P

Labile Po

Humic Po

Fulvic Po

Mod. labile Po Non-labile Po

Figure S1. Distribution of organic $P$ fractions before and after the soybean crop, at varying depths of an oxisol for the following tillage systems: NT1 - No-till in succession with Urochloa ruziziensis/soybean; NT2 - No-till in succession with Urochloa brizantha 'Piatã'/soybean; NT3 - No-till in succession with Panicum maximum 'Massai'/soybean; CT - Conventional tillage; NV - Fragment of native vegetation. 